Egyptian Poultry Science Journal

http://www.epsaegypt.com

ISSN: 1110-5623 (Print) - 2090-0570 (On line)

\title{
PRODUCTIVE PERFORMANCE AND IMMUNE RESPONSE OF BROILER CHICKS AS AFFECTED BY DIETARY THYME LEAVES POWDER
}

\author{
A. H. H. Ali, \\ Anim. and poult. Prod. Dep., Fac. of Agric., South Valley Univ., Qena, Egypt
}

Received: 16/01/2014

Accepted: 02/02/2014

\begin{abstract}
Ninety six unsexed one-day old, Ross 308 broiler chicks, were randomly divided into 4 treatment groups. Each treatment had 3 replicates with 8 chicks each. Chicks of each replicate were allocated in a cage with floor space $100 \times 50 \mathrm{~cm}\left(0.5 \mathrm{~m}^{2}\right)$. The basal experimental diets had 24 and $22 \%$ crude protein and 3009 and $3135 \mathrm{Kcal} \mathrm{ME} / \mathrm{kg}$ diet for the starter and grower diet, respectively. Chicks in treatment 1 were fed on basal diets without any addition (control). Whereas, in treatments 2, 3 and 4 chicks were received $0.5 \%, 1.0 \%$ or $1.5 \%$ thyme leaves powder (Thymus vulgaris), respectively. Supplementing broiler diets with thyme leaves powder significantly increased $(\mathrm{P}<0.05)$ final body weight (BW), body weight gain (BWG) from 4-6 and 0-6 weeks of age, glucose and HDLcholesterol compared with those of the control group. Moreover, supplementing broiler diets with thyme leaves powder improved $(\mathrm{P}<0.05)$ feed conversion ratio $(\mathrm{FCR})$ during growth periods of (4-6) and (0-6) weeks of age and decreased $(\mathrm{P}<0.05)$ cholesterol levels in the treated groups as compared with those of the control group. On the other hand, supplementing diets with thyme leaves powder had no significant effect $(\mathrm{P} \geq 0.05)$ on body weight at 21 days of age, feed intake (FI) during all periods, feed conversion ratio (FCR) from 0-3 weeks of age, hematocrit HCT, hemoglobin, total protein, albumin, globulin, albumin/ globulin ratio, LDL cholesterol, heterophils $(\mathrm{H})$, lymphocytes (L), monocytes, $\mathrm{H} / \mathrm{L}$ ratio, averages of serum haemagglutinin antibody (Ab.) titers against SRBC's at 6 weeks of age and spleen and bursa percentages. So, these data indicate that, supplementing thyme into the broiler diets improved productive performance without any detrimental impacts on immune responses and blood parameters.
\end{abstract}

Key Words: Thyme leaves, immune response, productive performance.

Corresponding author: attai73@yahoo.com 


\section{INTRODUCTION}

Herbs and herbal products are incorporated in poultry diets to replace synthetic products in order to stimulate or promote the effective use of feed nutrients which may subsequently result in more rapid body weight gain, higher production rates and improved feed efficiency (AlKhdri, 2013). Moreover, active components of herbs may improve digestion and stimulate the immune function in broilers (Ghazalah and Ali, 2008). Supplementation of spices and herbs could have many benefits to broilers health and performance such as having antioxidative potential (Hoffman and $\mathrm{Wu}, 2010$ ), antimicrobial activity (Dorman and Deans, 2000; Lee et al., 2004a; Steiner, 2009), enhancing digestion by stimulating endogenous enzymes (Al-Khdri, 2013).

Thyme (Thymus Vulgaris) is a member of Lamiaceae family with the main components of phenols, thymol (40\%) and carvacrol (15\%) (Mikaili et al., 2010). It is a pleasant smelling perennial herb, which grows in several regions in the world (Davis, 1982). Thyme is native to the Western Mediterranean region and Southern Italy. It is cultivated all over the world and has naturalized in some areas including the North- eastern of the US (AlKhdri, 2013). This herb is used traditionally for several medicinal purposes: respiratory diseases, antimicrobial, antinociceptive and etc (Demir et al., 2008). Thyme is used to suppress coughing, eases chest congestion and stimulates production of saliva (Lueng and Foster, 1996; Jellin et al., 2000; Barnes et al., 2002). Thymol (5-methyl-1-2isopropyl phenol) and carvacrol (5isopropyl-2-methyl phenol) are the main phenolic components in Thymus vulgaris (Masada, 1976), which have been both shown to possess potent antioxidant properties (Aeschbach et al., 1994; Hoffman and $\mathrm{Wu}, 2010)$. Antibacterial, anticoccidial and antifungal and no cytotoxic effects, preventing further mortality and improving general health of broilers were reported by Hagmuller et al. (2006) and Cross et al. (2007). The present study was carried out to investigate the effect of adding different levels of thyme leaves powder into broiler diets on the productive performance and immune response of broiler chicks.

\section{MATERIALS AND METHODS}

This study was carried out at the Poultry Farm, Department of Animal and Poultry Production, Faculty of Agriculture, South Valley University, Qena. It was designed to evaluate the effects of adding different levels of thyme leaves powder (Thymus vulgaris) into broiler diets on the productive performance (body weight, daily gain, feed intake and feed conversion) and immune responses of broiler chicks.

\section{Chicks and Housing:}

Ninety six unsexed one-day old; Ross 308 broiler chicks were obtained from a commercial local source and used in this study. Chicks were randomly divided into 4 treatment groups. Each treatment had 3 replicates with 8 chicks each (4 treatments $\mathrm{X} 3$ replicates $\mathrm{X} 8$ chicks $=96$ chicks).

Chicks in each replicate within each treatment had nearly similar initial live body weight. Chicks were reared in twotier wire floor battery in a windowless house including ventilation systems and heater that functions as needed, most often with micro-processor controls. The chicks of each replicate were allocated in a cage with slatted floor of iron.

\section{Diets and management:}

The experimental period was divided into two feeding phases, starter (from 0-3 weeks of age) and grower (from 4-6 weeks of age). The basal experimental diets had 24 and $22 \%$ crude protein and 3009 and $3135 \mathrm{Kcal} \mathrm{ME} / \mathrm{kg}$ diet for the 
starter and grower diets, respectively (Table 1). Experimental diets were formulated to meet the nutrients requirements of the broiler chicks (National Research Council, NRC, 1998).

was about $32^{\circ} \mathrm{C}$ during the first week old and it was gradually reduced by about $2^{\circ} \mathrm{C}$ weekly until about $24^{\circ} \mathrm{C}$ at the fourth week up to the end of experiment ( 6 weeks of age).

The experiment was included four treatments, in treatment 1 ; chicks were fed
Chicks have full access to feed and water during the experimental period. Artificial light was applied to maintain 23 hrs. light per day during the experimental period. The environmental temperature on basal diet without any addition (control). Whereas, in treatments 2,3 and 4 chicks were received $0.5 \%, 1.0 \%$ or $1.5 \%$ thyme (Thymus vulgaris) leaves powder, respectively. Chemical composition of thyme leaves is presented in Table (2).

Table (1): Composition of the starter and grower basal diets.

\begin{tabular}{|l|l|l|}
\hline \multicolumn{1}{|c|}{ Ingredients } & Starter & Grower \\
\hline Yellow corn & 52.59 & 56.04 \\
Soybean meal (44\% CP) & 32 & 30 \\
Corn gluten (60\% CP) & 9 & 6 \\
Vegetable oil & 2 & 4 \\
Premix & 0.3 & 0.3 \\
Dicalcium phosphate & 2 & 1.8 \\
Limestone & 1 & 1 \\
Lysine & 0.3 & 0.2 \\
Methionine & 0.25 & 0.125 \\
Choline chloride & 0.2 & 0.175 \\
Salt & 0.36 & 0.36 \\
Total & 100 & 100 \\
\hline Calculated values & \multicolumn{2}{|}{} \\
\hline Crude protein \% & 22 \\
ME (Kcal/kg) & 24 & 3135 \\
Calcium \% & 3009 & 0.86 \\
Av. Phosphorus \% & 0.91 & 0.43 \\
Methionine & 0.48 & 0.55 \\
Lysine \% & 0.74 & 1.27 \\
\hline
\end{tabular}

*Vitamins and minerals premix provided per kilogram of the diet: Vit A, 1000 IU; D3 2000 ICU; Vit E, 10 mg; Vit K, 1mg; B1, 10 mg; B2, 5 mg; B6, 1500 mg; B12, 10mg Pantothenic acid, $10 \mathrm{mg}$; Nicotinic acid, $30 \mathrm{mg}$; Folic acid, 1mg; Biotin, $50 \mathrm{mcg}$; Chloride, $500 \mathrm{mg}$; copper, $10 \mathrm{mg}$; iron, $50 \mathrm{mg}$; Manganese, $60 \mathrm{mg}$; Zinc, 50mg, and selenium, $0.1 \mathrm{mg}$. 
Table (2): Chemical composition of thyme leaves powder based on dry matter

\begin{tabular}{|l|l|}
\hline \multicolumn{1}{|c|}{ Items \% } & \multicolumn{1}{c|}{ Thyme } \\
\hline Moisture & 14.9 \\
Crude protein & 9.39 \\
Ether extract & 4.61 \\
Ash & 11.03 \\
Fiber & 15.62 \\
NFE (nitrogen free extract) & 44.45 \\
Total & 100 \\
\hline
\end{tabular}

\section{Hygiene:}

Chicks were vaccinated against Newcastle disease three times, firstly with Hitchner B1 on the $7^{\text {th }}$ day of age and twice with Lasota strain in drinking water at 12 and 24 days of age. At 14 and 28 days of age, chicks were vaccinated against infectious bursal disease (Gumboro).

\section{Productive performance:}

Live body weight and feed intake were recorded at $3^{\text {rd }}$ and $6^{\text {th }}$ weeks of age (two periods) for each replicate. Daily body weight gain and feed conversion ratio (gm feed: gm gain) were calculated for each replicate within each period of experimental periods $(0-3,4-6$ and $0-6$ weeks of age).

There was not any died chick during the whole experimental period from any treated or control groups.

\section{Physiological measurements:}

Fresh blood samples, each of about $2 \mathrm{ml}$, were collected from six chicks (chosen randomly) within each treatment at 5 and 6 weeks of age in heparinized tubes. However, blood samples were betided every time between 8:00 to 8:30 am. The blood samples were collected to determine hematological parameter, hemoglobin $(\mathrm{Hb})$ concentration using hemometer as the method described by Tietz (1982), hematocrit (HCT) according to Winderobe (1967).Two drops of blood from each sample were smeared on two glass slides.
The smears were stained within 2 to $3 \mathrm{hrs}$. of preparation using May-Gunwale, Giemsa Stains. One hundred leukocytes, including heterophils (H), lymphocytes (L), basophils, eosinophils and monocytes were counted on each slide and $\mathrm{H} / \mathrm{L}$ ratio was calculated by dividing the number of heterophils by that of lymphocytes as described by Sturkie (1986). Both slides were counted and the mean $\mathrm{H} / \mathrm{L}$ ratio was calculated for each chick.

At 5 weeks of age, six chicks from each treatment were injected intravenously in the brachial vein with $0.2 \mathrm{ml}$ of $10 \%$ suspension of packed sheep red blood cells (SRBC's). Sera were collected on the seventh day post immunization (at 6 weeks of age) and antibody titer against SRBC's was determined using the micro titer procedure described by Van der Zijpp and Leenstra (1980). Titers were expressed as the $\log _{2}$ of the reciprocal of highest dilution giving complete agglutination. Serum total protein and albumin were determined according to Doumas, (1971) and Witt and Trendelenburg (1982). Globulin concentration was calculated as the difference between total protein and albumin, then the ratio of albumin/ globulin was also calculated.

Total cholesterol was determined according to Watson (1960) and HDL by Warnick (1983), LDL by Assmann et al. (1984). 
Additionally, Plasma Glucose was determined according to the procedure of (Coles, 1986).

At 6 weeks of age six chicks (within average weight of treatment) from each treatment groups were slaughtered for estimation weights and percentages of spleen and bursa from live body weight.

\section{Statistical Analysis:}

Data collected were statistically analyzed by the analysis of variance with the General Linear Model (GLM) procedure of the SAS Institute (SAS, 1996). All statements of significance are based on the 0.05 level of probability. Significant differences among treatments were performed using Duncan's multiple range test (Duncan, 1955).

\section{RESULTS AND DISCUSSION}

Data of body weight at 21 and 42 days of age are listed in Table (3). Obtained data showed that all birds fed dietary thyme were significantly $(\mathrm{P}<0.05)$ heavier in body weight at 42 days of age than those of the control group. On the contrary, supplementing broiler diet with thyme leaves powder had no significant effect on body weight at 21 days of age. These results are in agreement with the findings of (Al-Jugifi, 2009; Toghyani et al., 2010; Al-Mashhadani et al., 2011; Foroughi et al., 2011) they mentioned that adding thyme powder or essential oil into the broiler`s diet or drinking water had a significant positive impact on the live body weight of broiler chickens.
On the other hand, the previous results of the present study are in contrast to some of the previous observations that indicated herbs, especially thyme, did not affect live body weight in the broiler chicks (Moorthy et al.,2009; Najafi and Torki, 2010; Rahimi et al., 2011; Sadeghi et al., 2011; Mohamed et al., 2012).

In the present study, data of daily body weight gain at (0-3), (4-6) and (0-6) weeks of age (Table, 3) indicates that adding thyme leaves powder to broiler diet increased $(\mathrm{P}<0.05)$ body gain during growth periods of (4-6) and (0-6) weeks of age. On the other hand, supplementing the broiler diet with thyme leaves powder had no significant effect on daily gain from 0-3 weeks of age.

These results are in agreement with the finding of (Al-Homidan, 2005; AlJugifi, 2009; Ademola et al., 2009; Thayalini et al., 2011; Kehinde et al., 2011; Al-Mashhadani et al., 2011; Mansoub and Myandoab, 2011) they reported that supplementation of broiler diet with thyme powder or essential oil through diet or drinking water had a positive significant effect on the broiler's body weight gain.

The higher body weight was noted in the broilers fed thyme may be due to the beneficial effects of these herbs in birds nutrition which includes improvement of endogenous digestive enzyme secretion and antibacterial, antiviral, antioxidant and anthelmintic actions. All these actions cause improvement in health, growth and performance of broiler (Rahimi et al., 2011). 
Table (3): Averages \pm (SE) of body weight (gm) and daily body weight gain (gm) as affected by the addition of thyme leaves powder into broiler chick diets.

\begin{tabular}{|c|c|c|c|c|c|}
\hline \multirow{2}{*}{$\begin{array}{l}\text { Items \& } \\
\text { ages } \\
\text { Thyme }\end{array}$} & \multicolumn{2}{|c|}{ Body weight (gm) } & \multicolumn{3}{|c|}{ Daily body weight gain (gm) } \\
\hline & $\begin{array}{c}21 \\
\text { days }\end{array}$ & $\begin{array}{c}42 \\
\text { days }\end{array}$ & $\begin{array}{c}0-3 \\
\text { weeks }\end{array}$ & $4-6$ & eeks \\
\hline Control 0 & 818 & 2010. & 36.6 & $.09^{\mathrm{b}}$ & 53.8 \\
\hline 0.5 & $817.50 \pm 6.96$ & $2381.25 \pm 13.01^{\mathrm{b}}$ & $36.55 \pm 0$ & $74.46 \pm 0.49^{a}$ & $55.51 \pm 0.31^{b}$ \\
\hline 1.0 & $816.25 \pm 6.41$ & $2418.33 \pm 9.28^{\mathrm{a}}$ & $36.49 \pm 0.30$ & $76.29 \pm 0.57^{\mathrm{a}}$ & $56.39 \pm 0.22^{\mathrm{a}}$ \\
\hline 1.5 & $830.83 \pm 5.42$ & $2423.75 \pm 12.77^{\mathrm{a}}$ & $37.18 \pm 0.26$ & $75.85 \pm 0.86^{\mathrm{a}}$ & $56.52 \pm 0.30^{\mathrm{a}}$ \\
\hline
\end{tabular}

Means within each column bearing different letter(s) are significantly different $(\mathrm{P}<0.05)$

Data of feed intake at (0-3), (4-6) and (0-6) weeks of age are listed in Table (4). Obtained data explained that supplementing broiler diet with thyme leaves powder had no significant effect on feed intake during the all studied periods. The reason for the lack of significant differences in feed intake for the broiler chicks during the whole period of experiment may be due to absence of elements or components in thyme that affect the bird appetite and then feed intake (Al-Khdri, 2013).

The feed intake results are in agreement with the findings of (El-Deek et al., 2002; Al-Homidan, 2005; Tekeli et al., 2006; Demir et al., 2008; Moorthy et al., 2009; Ademola et al., 2009; Najafi and Torki, 2010; Toghyani et al., 2010; Kehinde et al., 2011; Abdulkarimi et al., 2011; Al-Mashhadani et al., 2011; Mansoub and Myandoab, 2011; Foroughi et al., 2011; Rahimi et al., 2011) they concluded that supplementation of broiler diets with ginger and thyme did not affect the feed consumption compared to the control group.

In the present study supplementing broiler diet with thyme leaves powder had no significant effect on feed conversion ratio during the period from $0-3$ weeks of age. While, from 4-6 and 0-6 weeks of age supplementing diets with thyme leaves powder achieved the best feed conversion ratio compared with that of the control diet.

The results of feed conversion are in agreement with the findings of (Al-Jugifi, 2009; Al-Mashhadani et al., 2011; Foroughi et al., 2011) they found that supplementation broiler diet with thyme had a significant positive effect on the feed conversion ratio compared to the control diet. The improvement in feed conversion ratio as a result of adding thyme to broiler diets may be due to Volatile oil from thyme (Thymus vulgaris) which was assessed for antibacterial and antiviral activity as inhibitors of microbial growth (Dorman and Deans, 2000). Intestinal harmful bacteria has a negative effect on bile salts secretion (Feighner and Dashkevicz 1988). So lowering microbial growth may be due to higher synthesis or secretion of bile salts from liver. This phenomenon possibly leads to increase the fatty acids availability and, hence, performance improvement. 
Table (4): Averages \pm (SE) of daily feed intake (gm) and feed conversion ratio as affected by the addition of thyme leaves powder into broiler chick diets.

\begin{tabular}{|c|c|c|c|c|c|c|}
\hline \multirow{2}{*}{$\begin{array}{l}\text { Items \& } \\
\text { ages } \\
\text { Thyme } \\
\text { levels \% }\end{array}$} & \multicolumn{3}{|c|}{ Daily feed intake (gm) } & \multicolumn{3}{|c|}{ Feed conversion ratio } \\
\hline & $\begin{array}{c}0-3 \\
\text { weeks }\end{array}$ & $\begin{array}{c}4-6 \\
\text { weeks }\end{array}$ & $\begin{array}{c}0-6 \\
\text { weeks }\end{array}$ & $\begin{array}{c}0-3 \\
\text { weeks }\end{array}$ & $\begin{array}{c}4-6 \\
\text { weeks }\end{array}$ & $\begin{array}{c}0-6 \\
\text { weeks }\end{array}$ \\
\hline Control 0 & $56.73 \pm 0.37$ & $141.11 \pm 0.61$ & 98.92 & $1.55 \pm 0.004$ & $1.99 \pm$ & $1.84 \pm 0.005^{\mathrm{a}}$ \\
\hline 0.5 & $56.89 \pm 0.33$ & $144.26 \pm 1.23$ & $100.57 \pm 0.62$ & $1.56 \pm 0.021$ & $1.94 \pm 0.013^{b}$ & $1.81 \pm 0.001^{\mathrm{b}}$ \\
\hline 1.0 & $57.05 \pm 0.24$ & $144.63 \pm 1.25$ & $100.84 \pm 0.72$ & $1.56 \pm 0.016$ & $1.89 \pm 0.004^{\mathrm{c}}$ & $1.79 \pm 0.008^{\mathrm{c}}$ \\
\hline 1.5 & $57.20 \pm 0.45$ & $145.12 \pm 0.86$ & $101.16 \pm 0.53$ & $1.54 \pm 0.017$ & $1.91 \pm 0.011^{\mathrm{bc}}$ & $1.79 \pm 0.006^{c}$ \\
\hline
\end{tabular}

Means within each column bearing different letter $(\mathrm{s})$ are significantly different $(\mathrm{P}<0.05)$

\section{Physiological parameters:}

Obtained data of hemoglobin content, hematocrit percentage and glucose concentration presented in Table (5) indicated that no detrimental impact of thyme additions on hemoglobin content and hematocrit percentage. Toghyani et al. (2010) stated that treatments (Dietary treatments included control, antibiotic (flavophospholipol), and 5 and $10 \mathrm{~g} / \mathrm{kg}$ thyme powder) failed to induce any statistical impacts on hematological parameters of broilers including red and white blood cells count, hemoglobin and hematocrit values.
In the present study, thyme supplementation in broiler diets significantly increased glucose level compared to those of the control group. This result agreed with findings of Mansoub and Myandoab, (2011). The possible reason for increase serum glucose may be due to the abdominal lipids catabolism of gluconeogenesis process as feeding inclusion thyme by birds, since crushed thyme consumption in broiler chickens was reported to increase the serum glucose as mentioned by El-Ghousein and Al-Beitawi, (2009).

Table (5): Averages \pm (SE) of hematocrit, hemoglobin and glucose as affected by the addition of thyme leaves powder into broiler chick diets.

\begin{tabular}{|c|c|c|c|c|c|c|}
\hline \multirow{2}{*}{$\begin{array}{l}\text { Items \& } \\
\text { ages } \\
\text { Thyme } \\
\text { levels \% }\end{array}$} & \multicolumn{2}{|c|}{ Hematocrit \% } & \multicolumn{2}{|c|}{ Hemoglobin \% } & \multicolumn{2}{|c|}{ Glucose (mg/ dl) } \\
\hline & 35 days & 42 days & 35 days & 42 days & 35 days & 42 days \\
\hline Control 0 & $28.3 \pm 0.88$ & $28.3 \pm 0.33$ & $8.97 \pm 0.99$ & $8.87 \pm 0.95$ & $188.6 \pm 1.7^{\mathrm{b}}$ & $186.7 \pm 1.98^{b}$ \\
\hline 0.5 & $29.3 \pm 0.67$ & $28.67 \pm 0.88$ & $9.38 \pm 0.62$ & $9.83 \pm 0.65$ & $207.1 \pm 4.3^{\mathrm{a}}$ & $209.0 \pm 4.25^{\mathrm{a}}$ \\
\hline 1.0 & $28.67 \pm 0.88$ & $29.67 \pm 0.88$ & $9.93 \pm 0.89$ & $10.47 \pm 0.49$ & $212.2 \pm 5.99^{\mathrm{a}}$ & $217.2 \pm 3.27^{\mathrm{a}}$ \\
\hline 1.5 & $30.3 \pm 0.88$ & $31.3 \pm 0.33$ & $11.07 \pm 0.17$ & $11.17 \pm 0.82$ & $215.6 \pm 2.89^{\mathrm{a}}$ & $221.9 \pm 6.06^{\mathrm{a}}$ \\
\hline
\end{tabular}

Means within each column bearing different letter(s) are significantly different $(\mathrm{P}<0.05)$ 
Data of serum total protein, albumin, globulin and albumin/globulin ratio at $5^{\text {th }}$ and $6^{\text {th }}$ week of age are listed in Table (6). Obtained data showed that supplementing broiler diet with thyme leaves powder had insignificant effect on total protein, albumin, globulin and albumin/globulin ratio at $5^{\text {th }}$ and $6^{\text {th }}$ week of age. Toghyani et al. (2010 and 2011) reported that adding thyme powder at levels of 5 and $10 \mathrm{~g} / \mathrm{kg}$ diet did not have any effects on the total protein, albumin, A/G ratio.

Table (6): Averages \pm (SE) of serum total protein, albumin, globulin and albumin/globulin ratio as affected by the addition of thyme leaves powder into broiler chick diets.

\begin{tabular}{|c|c|c|c|c|c|c|c|c|}
\hline \multirow{2}{*}{$\begin{array}{l}\text { Items \& } \\
\text { ages } \\
\text { Thyme } \\
\text { levels \% }\end{array}$} & \multicolumn{2}{|c|}{$\begin{array}{l}\text { Total protein } \\
\text { (g/ dl ) }\end{array}$} & \multicolumn{2}{|c|}{$\begin{array}{l}\text { Albumin } \\
\text { (g/ dl ) }\end{array}$} & \multicolumn{2}{|c|}{$\begin{array}{l}\text { Globulin } \\
\text { (g/ dl ) }\end{array}$} & \multicolumn{2}{|c|}{ Alb./Glob. } \\
\hline & $\begin{array}{c}35 \\
\text { days }\end{array}$ & 42 & & 42 & $\begin{array}{c}35 \\
\text { days }\end{array}$ & & $\begin{array}{c}35 \\
\text { days }\end{array}$ & $\begin{array}{c}42 \\
\text { days }\end{array}$ \\
\hline & 00 & & & 4 & 0.18 & & & \\
\hline 0.5 & & & & $1.58 \pm$ & \pm 0.07 & 1.16 & & \\
\hline 1. & & & & & \pm 0.07 & & & \\
\hline 1.0 & $3.53 \pm 0.0$ & $.04 \pm 0$. & $.94 \pm 0.27$ & $1.64 \pm 0$. & $.59 \pm 0.19$ & $1.39 \pm 0.11$ & $1.31 \pm 0.36$ & $1.20 \pm 0.18$ \\
\hline
\end{tabular}

Table (7) summarizes of serum lipids. The data revealed that, no significant influence of experimental diets on LDL- cholesterol, although, birds fed dietary thyme at all levels resulted in a marked $(\mathrm{P}<0.05)$ decrease in total cholesterol and increase in HDLcholesterol concentration compared to control group. These results are in agreement with findings of (Ademola et al., 2009; Saeid et al., 2010; Tekeli et al., 2011; Toghyani et al., 2011; AlMashhadani et al., 2011; Mohamed et al., 2012) they used ginger and thyme through broiler diet and drinking water and found that there was significant decrease in the cholesterol concentration compared with the control group. Moreover, Toghyani et al., (2010) stated that addition of thyme powder at $10 \mathrm{~g} / \mathrm{kg}$ diet significantly $(\mathrm{P}<0.05) \quad$ increased
HDL-cholesterol concentration but triglyceride, total and LDL cholesterol concentrations were not influenced. The significant decrease in the total cholesterol levels by thyme supplementation may have resulted from the antioxidant properties of the phenolic components containing thyme. Since, these antioxidants have the ability to increase the synthesis of nitric oxide which has the ability to cause vasodilation, resulting in the clearance and prevention of the deposition of excess cholesterol in the blood vessels. These are in agreement with Rahim et al., (2011). Lee et al. (2004b) reported that thyme oil supplementation resulted in a decrease in the total cholesterol and triglyceride levels, but HDL-cholesterol was increased. 
Table (7): Averages \pm (SE) of serum cholesterol, LDL-cholesterol and HDLcholesterol as affected by the addition of thyme leaves powder into broiler chick diets.

\begin{tabular}{|c|c|c|c|c|c|c|}
\hline \multirow{2}{*}{$\begin{array}{l}\begin{array}{r}\text { Items \& } \\
\text { ages }\end{array} \\
\text { Thyme } \\
\text { levels \% }\end{array}$} & \multicolumn{2}{|c|}{$\begin{array}{c}\text { Cholesterol } \\
(\mathrm{mg} / \mathrm{dl})\end{array}$} & \multicolumn{2}{|c|}{ LDL (mg/ dl) } & \multicolumn{2}{|c|}{ HDL (mg/ dl) } \\
\hline & 35 & 42 days & 35 & 42 & 35 & 42 \\
\hline Control 0 & $125.2 \pm 2$ & $127.0 \pm$ & 39.10 & 38.83 & $64.5 \pm$ & 65.3 \\
\hline 0.5 & $117.97 \pm 1.78^{b}$ & $120.5 \pm 2.86^{\mathrm{ab}}$ & $37.63 \pm 1.32$ & $37.63 \pm 0.64$ & $76.23 \pm 1.77^{b}$ & $80.3 \pm 1.84^{\mathrm{b}}$ \\
\hline 1.0 & $115.37 \pm 1.71^{\mathrm{b}}$ & $113.0 \pm 1.40^{\mathrm{c}}$ & $37.03 \pm 1.52$ & $36.13 \pm 1.06$ & $82.33 \pm 2.27$ ab & $87.63 \pm 1.95^{\mathrm{a}}$ \\
\hline 1.5 & $114.53 \pm 2.31^{\mathrm{b}}$ & $114.67 \pm 1.93^{\mathrm{bc}}$ & $38.57 \pm 1.13$ & $36.87 \pm 1.22$ & $84.97 \pm 1.74^{\mathrm{a}}$ & $88.87 \pm 1.81^{\mathrm{a}}$ \\
\hline
\end{tabular}

Means within each column bearing different letter(s) are significantly different $(\mathrm{P}<0.05)$

Percentages of white blood cells: monocytes (M), heterophils $(\mathrm{H})$, lymphocytes (L) and $\mathrm{H} / \mathrm{L}$ ratios are presented in Table (8). Obtained data explained that the differences between all treated and the control groups were not significant.
Toghyani et al. (2010 and 2011) stated that the effect of thyme addition into broiler diets on monocytes (M), heterophils $(\mathrm{H})$, lymphocytes (L), heterophil to lymphocyte and albumin to globulin ratios did not significantly differ among treatments.

Table (8): Averages $\pm(\mathrm{SE})$ of percentage white blood cells differentiation: monocytes $(\mathrm{M})$, heterophils $(\mathrm{H})$, lymphocytes $(\mathrm{L})$ and $\mathrm{H} / \mathrm{L}$ ratio as affected by the addition of thyme leaves powder into broiler chick diets.

\begin{tabular}{|l|l|l|l|l|l|c|c|c|}
\hline $\begin{array}{l}\text { Items \& } \\
\text { ages } \\
\begin{array}{l}\text { Thyme } \\
\text { levels \% }\end{array}\end{array}$ & \multicolumn{2}{|c|}{ Lymphocytes } & \multicolumn{2}{c|}{ Heterophils } & \multicolumn{2}{c|}{ Monocytes } & \multicolumn{2}{c|}{ H/L ratio } \\
\cline { 2 - 9 } & $\mathbf{3 5}$ days & $\mathbf{4 2}$ days & $\mathbf{3 5}$ days & $\mathbf{4 2}$ days & $\begin{array}{c}\mathbf{3 5} \\
\text { days }\end{array}$ & $\begin{array}{c}\mathbf{4 2} \\
\text { days }\end{array}$ & $\begin{array}{c}\mathbf{3 5} \\
\text { days }\end{array}$ & $\begin{array}{c}\mathbf{4 2} \\
\text { days }\end{array}$ \\
\hline Control 0 & $55.67 \pm 0.88$ & $59.33 \pm 0.88$ & $26.33 \pm 0.88$ & $27.67 \pm 0.33$ & $4.67 \pm 0.67$ & $5.0 \pm 0.58$ & $0.47 \pm 0.024$ & $0.47 \pm 0.004$ \\
\hline $\mathbf{0 . 5}$ & $56.67 \pm 0.67$ & $60.0 \pm 1.73$ & $27.67 \pm 0.67$ & $28.33 \pm 0.88$ & $5.67 \pm 0.33$ & $5.67 \pm 0.33$ & $0.49 \pm 0.006$ & $0.47 \pm 0.022$ \\
\hline $\mathbf{1 . 0}$ & $57.33 \pm 0.88$ & $62.0 \pm 0.58$ & $29.0 \pm 1.00$ & $29.33 \pm 0.67$ & $5.33 \pm 0.88$ & $5.33 \pm 0.33$ & $0.51 \pm 0.0128$ & $0.47 \pm 0.015$ \\
\hline $\mathbf{1 . 5}$ & $58.33 \pm 0.33$ & $63.33 \pm 0.67$ & $28.33 \pm 0.33$ & $30.67 \pm 0.88$ & $6.3 \pm 0.33$ & $6.00 \pm 0.33$ & $0.49 \pm 0.008$ & $0.48 \pm 0.018$ \\
\hline
\end{tabular}

Averages of serum haemagglutinin antibody (Ab.) titers at 6 weeks of age, spleen percentage and bursa percentage are listed in Table (9). Obtained data elucidated that, using thyme in broiler diets did not show any significant effect on Ab. titers at 6 weeks of age, spleen percentage and bursa percentage. Toghyani et al. (2010) stated that the effect of experimental diets (Dietary treatments included control, antibiotic (flavophospholipol), and 5 and
$10 \mathrm{~g} / \mathrm{kg}$ thyme powder) failed to have any statistical effect on antibody titer against Newcastle and influenza viruses and also SRBC at 28 day of age $(\mathrm{P}>0.05)$. Moreover, (El-Deek et al., 2002; Toghyani et al., 2010; Najafi and Torki, 2010; Sadeghi et al., 2011; Rahimi et al., 2011) did not find any effect of ginger and thyme on the relative weight of bursa and spleen in the broiler chicks. 
Table (9): Averages \pm (SE) of spleen percentage, bursa percentage and haemagglutinin antibody $(\mathrm{Ab})$ titers against (SRBC's) as affected by the addition of thyme leaves powder into broiler chick diets.

\begin{tabular}{|l|l|l|l|}
\hline Thyme levels \% & \multicolumn{1}{|c|}{ Ab. } & \multicolumn{1}{c|}{ Spleen \% } & \multicolumn{1}{c|}{ Bursa\% } \\
\hline Control 0 & $5.33 \pm 0.612$ & $0.19 \pm 0.014$ & $0.13 \pm 0.006$ \\
\hline $\mathbf{0 . 5}$ & $6.0 \pm 0.458$ & $0.19 \pm 0.019$ & $0.14 \pm 0.003$ \\
\hline $\mathbf{1 . 0}$ & $5.87 \pm 0.328$ & $0.18 \pm 0.018$ & $0.15 \pm 0.010$ \\
\hline $\mathbf{1 . 5}$ & $5.4 \pm 0.611$ & $0.19 \pm 0.018$ & $0.16 \pm 0.004$ \\
\hline
\end{tabular}

\section{CONCLUSION}

Considering the results of the current study it could be concluded that supplementation of thyme powder, particularly the higher levels (1.0 or $1.5 \%)$

\section{REFERENCES}

Abdulkarimi, R., A. M. Aghazadeh and M. Daneshyar, (2011). Growth performance and some carcass characteristics in broiler chickens supplemented with thymus extract (thymus vulgaris) in drinking water. Journal of American Science. 7 (11): $400-405$.

Ademola, S.G,. G.O. Farinu and G.M. Babatunde, (2009). Serum lipid, growth and hematological parameters of broilers fed garlic, ginger and their mixtures. World Journal of Agricultural Sciences. 5 (1): 99 - 104.

Aeschbach R, J. Loliger, B. C. Scott, A. Muscia, J. Butler, B. Halliwell, (1994). Antioxidant action of thymol, carvacrol, 6- ginerol, zinezerone and hydroxytyrosol. Food Chemistry Toxicology. 32: 31-36.

AL-Homidan, A. A., (2005). Efficacy of using different sources and levels of in broiler diets has the potential to improve productive performance like most growth promoters without any detrimental impacts on immune responses and blood parameters of the birds.

allium cepa, allium sativum and zingiber ofjicinale on broiler chick's performance. Saudi Journal of Biological Sciences. 12 (2): 96 102.

Al-Jugifi, W. I. K., (2009). Effect of different levels of thyme vulgaris on performance of broiler chicken. Al - Anbar Journal of Veterinary Sciences. 2(1): $111-120$.

Al-Khdri, A. M. A., (2013). Effect of ginger (zingiber officinale) and thyme (thymus vulgaris) dietary supplementation on productive and immunological performance of broiler. Faculty of Agriculture and Forestry School of Animal Production Kurdistan Regional Government-Iraq master thesis

Al-Mashhadani, E. H., Farah, K. Al-Jaff and Y. M. Farhan, (2011). Effect of anise, thyme essential oils and their mixture (eom) on broiler performance and some physiological traits. Egypt. Poult. Sci. 31 (2): 481-489. 
Assmann, G, H.V. Jabs, U. Kohnert, W. Nolte and H. Schriewer, (1984). LDL-cholesterol polyvinyl sulphate method (kit of LDL) Clin. Chem. Acta., 140:77-83.

Barnes, J., L. A. Anderson and J.D. Phillipson, (2002). Herbal medicines. A guide for healtheare profe second edition, london: pharmaceutical pres.

Coles E. H., (1986). Veterinary clinical pathology. 4th Ed. W. B. Saunders company Philadelphia , London. Toronto.

Cross D. E., R. M. Mcdevitt, K. Hillman and T. Acamovic, (2007). The effect of herbs and their associated essential oils on performance, dietary digestibility and gut micro flora in chickens from 7 to 28 days of age. British Poultry Science. 48(4): 496-506.

Davis, P. H., (1982). Flora of turkey and the east aegean islands. Vol.7, 320354 Pp, Univer- Sity Pres, Edinburgh.

Demir, E, K. Kilinc, Y. Yildirim, F. Dincer and $H$. Eseceli, (2008). Comparative effects of mint, sage, thyme and flavomycin in wheatbased broiler diets. Archiva Zootechnica. 11 (3): 54-63.

Dorman, H. J. D. and S. G. Deans, (2000). Antimicrobial agents from plants: antimicrobial activity of plant volatile oils. Journal of Applied Microbiology. 88: 308-316.

Doumas B., (1971). Colorimetric determination of serum albumin. Clin.Chem.Acta. 31: 400-403.

Duncan, D. B., (1955). Multiple ranges and multiple F-test. Biometric, 11: 1042.

El-Deek, A. A., Y. A. Attia and M. M. Hannfy, (2002). Effect of anise (pimpinella anisum), ginger (zingiber officinale roscoe) and fennel (foeniculum vulgare) and their mixture on performance of broilers. Arch. Geflu“Gelk. 67 (2): $92-96$

El-Ghousein, S.S., Al-Beitawi, N.A., (2009). The effect of feeding of crushed Thyme (Thymus vulgaris) on growth, blood constituents, gastrointestinal tract and carcass characterestrics of broiler chickens. J. Poult. Sci. 46:100-104.

Feighner, S.D and M. P. Dashkevicz, (1988). Effect of dietary carbohydrates on bacterial cholytaurinydrolase in poultry intestinal homogenates. Applied and Environmental Microbiology. 54: 337- 342.

Foroughi, A. R., H. M. Torghabeh and H. Salen, (2011). The effect of essential oil of thyme (thyme vulgaris) on performance and humoral immune response broiler chicken. Agricultural Journal. 6 (6): $299-302$.

Ghazalah, A.A. and A.M. Ali, (2008). Rosemary leaves as a dietary supplement for growth in broiler chickens. International Journal of Poultry Science. 7: 234-239.

Hagmuller, W., M. Jugl-Chizzola, K. Zitterl-Eglseer, C. Gabler, J. Spergser, R. Chizzola and $\mathrm{C}$. Franz, (2006). The use of thymi herba as feed additive $(0.1 \%, 0.5 \%$, $1.0 \%)$ in weanling piglets with assessment of the shedding of haemolysing e. Coli and the detection of thymol in the blood plasma. Bulgarian Journal of Veterinary Medicine. 119: 50-54.

Hoffman-Pennesi, D. and C. Wu, (2010). The effect of thymol and thyme oil feed supplementation on growth performance, serum antioxidant levels and cecal salmonella populationin broilers. The Journal of Applied Poultry Research. 19 (4): $432-443$.

Jellin, J. M., F. Batz and K. Hitchens, (2000). Natural medicines 
comprehensive database. Third Edition. California: Therapeutic Research Faculty.

Kehinde, A. S., C. O. Obun, M. Inuwa and O. Bobadoye, (2011). Growth performance, haematological and serum biochemical indices of cockerel chicks fed ginger (zingiber officinale) additive in diets. Animal Research International. 8 (2): 1398 $-1404$.

Lee K. W., H. Everts and A. C. Beynen, (2004a). Essential oils in broiler nutrition. International journal of poultry science. 3:738-752.

Lee, K.W., Everts, H., Kappert, H.J., Wouterse, H., Frehner, M. \& Beynen, A.C., (2004b). Cinnamaldehyde, but not thymol, counteracts the carboxymethyl cellulose-induced growth depression in female broiler chickens. Int. J. Poult. Sci. 3 (9), 608-612.

Lueng, A. Y. and S. Foster, (1996). Encyclopedia of commonnatural ingredients used in food, drug, cosmetics. Second Edition. New York,NY:Wiley \& Sons.

Mansoub, N. H. and M. P. Myandoab, (2011). The effect of different levels of thyme on performance, carcass traits and blood parameters of broilers. Annals of Biological Research. 2 (4): 379 - 385.

Masada Y., (1976). Analysis of oils by gas chromatography and mass spectrometry. Johan Wiley and Sons.

Mikaili, P., M.A Mohammad Nezhady, J. Shayegh and M.H Asghari, (2010). International Journal of Academic Research. 2 (6). November, Part II.

Mohamed, A. B., M. A. M. Al-Rubaee and A. Q. Jalil, (2012). Effect of ginger (zingiber officinale) on performance and blood serum parameters of broiler. International
Journal of Poultry Science. 11 (2): 143-146.

Moorthy, M., S. Ravi, M. Ravikumar, K. Viswanathan and S. C. Edwin, (2009). Ginger, pepper and curry leaf powder as feed additives in broiler diet. International Journal of Poultry Science. 8 (8): 779 - 782.

Najafi, P. and M. Torki, (2010). Performance, blood metabolites and immunocompetaence of broiler chicks fed diets included essential oil of medicinal herbs. Journal of Animal and Veterinary Advances. 9 (7): $1164-1168$.

National Research Council, NRC, (1998). Nutrient Requirements of Poultry, 10th ed. Washington, DC, National Academy Press.

Rahim A., Mohsen D., and Alimirza A., (2011). Thyme (Thymus vulgaris) extract consumption darkens liver, lowers blood cholesterol, proportional liver and abdominal fat weights in broiler chickens. Italian Journal of Animal Science, 10 (2): 101-105.

Rahimi, S., Z. T. Zadeh, M. A. K. Torshizi, R. Omidbaigi and $H$. Rokni, (2011). Effect of the three herbal extracts on growth performance, immune system, blood factors and intestinal selected bacterial population in broiler chickens. Journal of Agricultural Science and Technology. 13: 527 539.

Sadeghi, G. H., A. Karimi, S. P. Jahromi, T. Aziz and A. Daneshmand, (2011). Effect of cinnamon, thyme and turmeric infusions on the performance and immune response in of 1 to 21 day-old male broilers. Brazilian Journal of Poultry Science. .14(1): 15-20.

Saeid, J. M., A. B. Mohamed and M. A. AL-Baddy, (2010). Effect ofaqueous extract of ginger (zingiber officinale) on blood 
biochemistry parameters of broiler. International Journal of Poultry Science. 9 (10): 944-947.

SAS, (1996). SAS User's Guide, statistics (6.2th Ed.) Cary NC: SAS Institute Inc.

Steiner T., (2009). Phytogenics in animal nutrition: natural concepts to optimize gut health and performance. Nottingham University Press, Nottingham, UK, (ISBN-13: 978-1-904761-71-6).

Sturkie, P.D, (1986). " Avian Physiology". by P.D. Sturkie, 4th ed., SpringerVerlag, New York. INC.

Tekeli, A., L. Çelik, H. R. Kutlu and M. Görgülü, (2006). Effect of dietary supplemental plant extracts on performance, carcass characteristics, digestive system development, intestinal microflora and some blood parameters of broiler chicks. Proceedings of 12th European Poultry Conference, Sept. 10 - 14, Verona, Italy, Pp: $307-$ 308.

Tekeli, A., H. R. Kutlu and L. Celik, (2011). Effects of z. Officinale and propolis extracts on the performance, carcass and some blood parameters of broiler chicks. Current Research in Poultry Science. 1 (1): $12-23$.

Thayalini, K., S. Shanmugavelu, P. M. Saminathan, M. S. Siti Masidayu, Y. Nor Idayusni, H. Zainuddin, C. A. Nurul Akmal, and H. K. Wong, (2011). Effects of cymbopogon citratus leaf and zingiber officinale rhizome supplementation on growth performance, ileal morphology and lactic acid concentration in broilers. Malaysian Journal of Animal Science. 14: 43-49.
Tietz N. W., (1982). Fundamental of Clinical Chemistry. Edition by Norbert Sanrders Company, Philadelphia, USA.

Toghyani, M., M. Tohidi, A. A. Gheisari and S. A. Tabeidian, (2010). Performance, immunity, serum biochemical and hematological parameters in broiler chicks fed dietarythyme as alternative for an antibiotic growth promoter. African Journal of Biotechnology. 9 (40): 6819-6825.

Toghyani, M., M. Toghyani, M. Mohammadrezaei, S. A. Tabeidian and G. Ghalamkari, (2011). Effect of cocoa and thyme powder alone or in combination on humoral immunity and serum biochemical metabolites of broiler chicks. International Proceedings of Chemical, Biological \& Environmental Engineering. 22: 114 $-118$.

Van der Zijpp, A. J. and F. R. Leenstra, (1980). Genetic analysis of the humoral immune response of White Leghorn chickens. Poult. Sci., 59: 1363-1369.

Warnick, (1983). HDL - cholesterol procedure No OSSgg (kit of HDL cholesterol) selection methods Clin. Chem., 10: $91-99$.

Watson M., (1960). A method for determination of cholesterol. Clin. Bioch. 58(4): 379-382.

Winderobe M. M., (1967). Clinical Hematology. 6th Ed. pp., 414419.Lea and Febiger, Philadelphia, USA.

Witt L., and C. Trendelenburg, (1982). A method for rapid determenation of total protein of serum, J. P. Clin., Biochem., 220-235. 


\title{
الملخص العربى \\ الاداء الانتاجى والاستجابة المناعية لكتاكيت التسمين تحت تاثير استخدام علائق اوراق الزعتر المطحونة
}

\author{
قسم الاتتاج الحبوانى و الدواجن ـ كلبة الزراعة حسين - جامعة جنوب الوادى ـ قنا ـ مصر
}

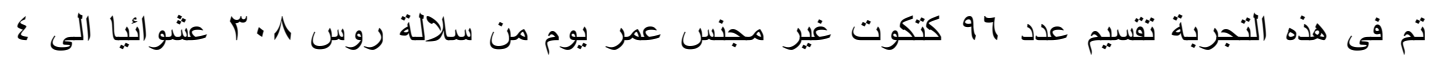

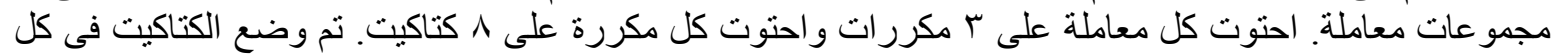

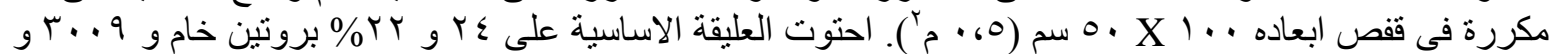

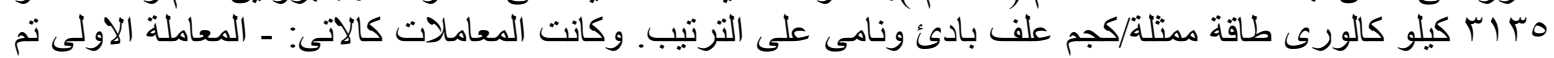

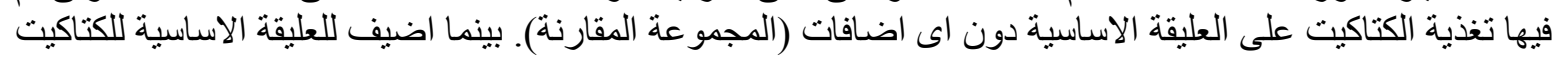

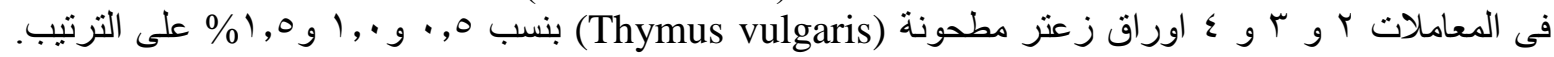

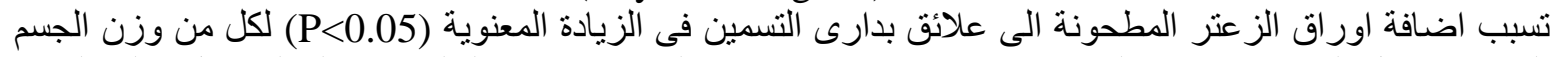

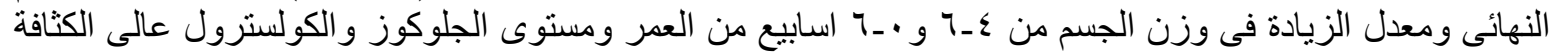

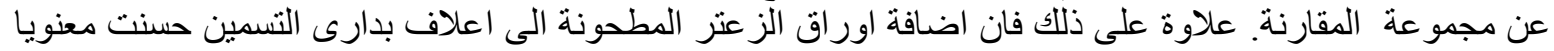

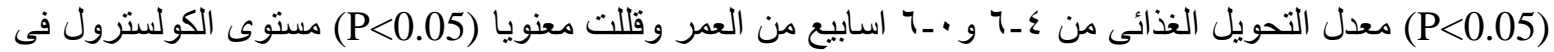

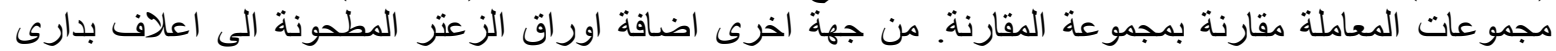

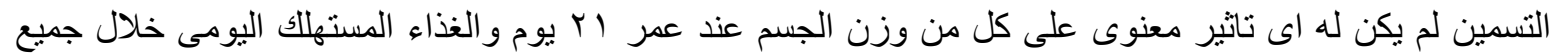

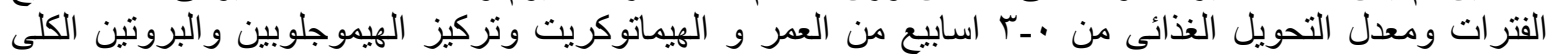

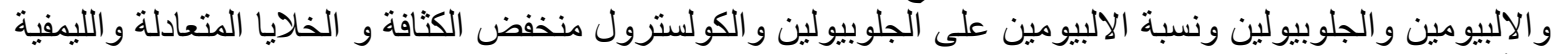

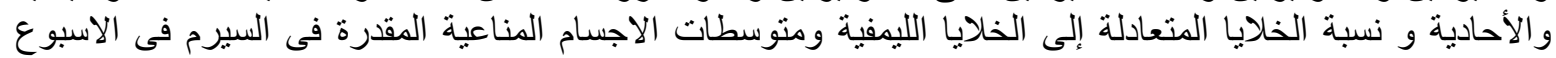

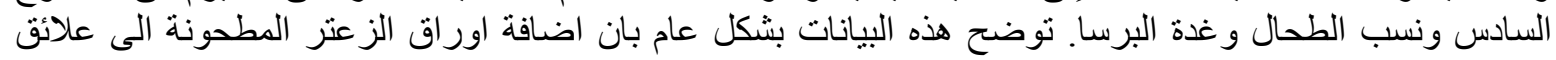

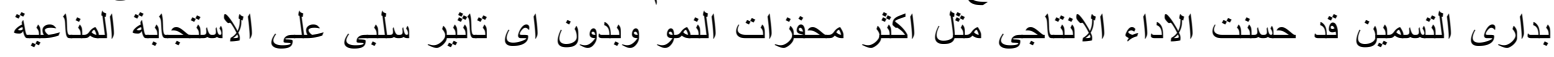
ومكونات الدم لكتاكيت اللحم. 